石油技術協会誌 第 64 巻 第 4 号 (平成11年 7 月)

JOURNAL OF THE JAPANESE ASSOCIATION FOR PETROLEUM TECHNOLOGY

VOL. 64, NO. 4 (July, 1999)

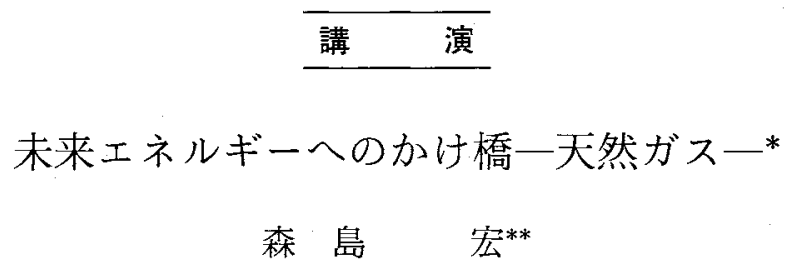

(Received July 8, 1999 : accepted July 16, 1999)

\title{
Natural gas bridging to the future energy
}

\section{Hiroshi Morishima}

\begin{abstract}
Historical shifts of the four main energy resources-from wood, to coal, to petroleum, and to natural gas - have been investigated from the viewpoints of technology, energy efficiency and environment. It is concluded that the driving force for the energy shifts is desire of human beings to get resources with higher thermal value, or higher hydrogen content, and that technology is a tool or measure - rather than restriction-by which human beings pursue that desire. Having the highest hydrogen to carbon ratio and the lowest carbon to hydrogen ratio, natural gas is stated as the ultimate energy resources, both in terms of energy efficiency and in the environmental issues.

The role of natural gas in the 21st century has been examined from four viewpoints : resources and reserves, global warming, energy efficiency, and transportation and delivery. It is concluded that the ultimate recoverable reserves of natural gas will probably be increased and meet the world demand for energy in the next century. The effects of natural gas in reducing $\mathrm{CO}_{2}$ are stressed together with the importance of carbon sequestration to stabilize the emission of global warming gases. The efficiency, present state and future outlook are demonstrated by various gas utilizing technologies, such as cascade use of energy in combined cycle power generation and co-generation, natural gas vehicles, fuel cells, and combination technology with other types of energy. The importance of constructing world gas supply networks is emphasized in order that as many people as possible can enjoy the merits of natural gas.

It is proposed that hydrogen will be an ideal and ultimate energy in the 22nd century and beyond, providing the highest energy efficiency and absolutely no environmental damage, and that natural gas, which has the lowest $\mathrm{CO}_{2}$ emission, is a reasonable bridge to it as the most economic source, reservoir and carrier of hydrogen.
\end{abstract}

Key words : energy shifts, natural gas, gas reserves and resources, unconventional natural gas, global warming, carbon sequestration, energy efficiency, energy cascade, gas technology, gas supply network, future energy system, hydrogen gas

* 平成11年 5 月 25 日, 平成11年度石油技術協会春李講演会の特 別講演 This special lecture was delivered at the 1999 JAPT Annual Meeting held in Makuhari, Chiba, Japan, May 25, 1999.

**第22回世界ガス会議東京大会組織委員会 The National Organizing Committee of the 22nd World Gas Conference Tokyo 2003

Copyright(C) 1999, JAPT

\section{1. 序言}

2003年に東京において開かれる第22回世界ガス会議 は，日本そしてアジアで初めて開催されるとともに，世 界のガス産業関係者が21世紀になって初めて一堂に会す る場ともなる。この会議に携わるにあたり，来るべき21 世紀之その先の未来のエネルギーの在り方につき, 個人 の立場から，中長期的観点に立った展望を試みたい。 
人類は，その歴史の中で, 木材から始まって, 石炭, 石油，そして天然ガスに至る主要な 4 種のエネルギ一資 源を用いてきた。その利用の変遷と要因を振り返ること によって，人類がエネルギー資源に何を求めてきたかを 明らかにし，さらに未来のエネルギーに求められるあの は何かを論じたい。そして天然がスが21世紀のエネル ギー資源の主役となりうるかを検証し，最後にその先の 未来エネルギー像とそれへのかけ橋としての天然ガスの 位置づけを考察したい。

\section{2.人類はどんなエネルギー資源を使ってきたか}

\section{1 人類によるエネルギー資源利用の变遷}

人類の最初のエネルギー資源の用途は，火をたくこと であった。火は暖房に，照明に，食物の調理に，道具の 加工に，あるいは野獣に対する防御に，さまざまな面で 人類を助け，本来生物学的には弱い人間があらゆる環境 に適応することを可能にした。火の使用こそが人類を生 態系の頂点に，万物の霊長になることを可能にした人類 史上最す重要な出来事の 1 つであるといえよう。

(1) 木 材

木材は最も身近な゙資源であり，人類が火を使い始めた ときからの燃料であった。木材を含むバイオマスは基本 的に再生可能であり, 原始時代から古代，中世を通じて 人類社会発展のエネルギー消費を支えてきた。近代に至 るまでは，エネルギ一消費は基本的に木材の供給可能な 範囲で行われ，自然と調和したエネルギ一経済システム が成り立っていた。

(2) 石 炭

木材に比し格段に高い熱量を持つ石炭は，産業革命の 進行と，エネルギー消費の急增とともに，19世紀の半 ば，木材に替わって燃料の主役となった。19世紀になる と乾留によるガス，コークス，コールタールなどの各成 分の分離と，それらを原料とする石炭化学む発展し，見 代の化学工学の基礎を形成した。石炭は木材と異なり再 生可能な資源ではないが，その埋蔵量が膨大であること から, 資源量の限界が意識されることなく, 採掘利用さ れてきた。

(3) 石油

石油は20世紀の現代文明の発展をもたらした資源工ネ ルギーである。産業として出発したのは，19世紀の後 半, 米国のドレークによる不油井の掘削であった。当初 は，燃料ではなく，照明のための灯油の原料を得ること が目的であったことは，ょく知られている。石油からの 灯油は良質の明かりを求める人々に歓迎され，石油産業 は短時間のうちに米国だけに限らず世界各地にも広がっ た。照明の主役はその後電気へと移ったが，石油の用途
は19世紀末からガソリン，軽油など，動力機関の燃料用 原料へと搪大していった。また20世紀になってからは， 石油を原料之する石油化学む発展した。石油惊石炭に比 して環境に与える污染が少なく, 産業革命以来発展した 都市生活に必要な発電，暖房用のエネルギー源として使 用された。交通機関の燃料としても，固体の石炭に比し て圧倒的な利便性，エネルギー効率を有した。こうして 石油は，1960年代に石炭を拢いてエネルギー資源の第 1 位に躍り出た。急激な石油の需要增は，1970年代には 2 度の石油危機を引き起こした。

\section{(4) 天然ガス}

天然ガスの大規模な利用は，米国では第 2 次世界大戦 前から，そして欧州，ロシアでは戦後になってから本格 的に始まった。発熱量が高くエネルギー効率のよい天然 ガスの需要は急速に増大した。1960年代加らは液化天然 ガス（LNG）の海上輸送によって，近隣に大規模ガス田 を持たない日本などの国において市大規模利用が進むこ ととなった。メタンを主成分とする天然がスは，地球環 境に優しい資源エネルギーとしても評価されてきた。欧 米，ロシアでは，天然ガスはすでに一次エネルギーにお いて石油上同等あるい石油以上の比率を占めている。 全世界ではまだその比率は石活扔よび石炭に次いで第3 位であるが，今後急速に増大し，21世紀におけるエネル ギーの主役になるあの之期待されている。

\section{2 エネルギー利用の变遷を左右した技術力の発展}

(1) 採取技術

人類社会の発展の初期，技術が不十分な時代において は，地上資源である木材のみが採取可能な資源であっ た。

地下資源である石炭は木材と同じく固体であり，採取 を除いて基本的には木材に関する技術が生かされた。当 初は露頭からの採取であったが，採炭深度が増すにつれ て坑道掘となり, 掘削, 排水, 換気, 運搬, 各種探查技 術なよ゙各分野に高度の技術を必要とするようになった。 これらの条件が整ってきた18世紀になって大量採掘が可 能となり，19世紀後半には石炭は木材を抜いてェネル ギー資源の主役になることができた。

地下資源の中でも，流体である石油，ガスの発見，生 産には，より高度の技術を要し，19世紀加ら20世紀にか けての石油地質学および油層工学の発展ととあに, 発見 量, 生産量が增大していった。

（2）利用技術

人類によるエネルギー資源の最初の利用は，火をおこ すことであった。他の動物が恐れる火を制御する技術を 獲得したときから，人類は生物としての限界を大きく超 え, 活動能力, 環境適用範囲を広げはじめた。アフリカ 
で発生した人類が，環境の異なるアジア，ヨーロッパヘ と移動し始めた時期も，火在使い始めた今から約 100 万 年前であるといかれる。

火による照明あまた，人類にとって重要な用途であっ た。人類の照明に対する欲求は極めて強力なものであ り，各種の照明材料を求める努力が続けられた。産業革 命後, 急速に社会, 経済活動が発展すると, 欧米では鯨 油が求められ，19世紀には欧米の捕鯨船が世界各地へ進 出し，これが米国の日本開国要求の直接のきっかけとも なった。さらに, 石油産業の発端となった19世紀半ばの 米国に扮けるドレークによる石油開発 1 号井の掘削る, また灯油の原料となる原油の採取を目的としたもので あった。石炭ガスによる照明も，電気照明が普及するま で灯油と並ぶ重要な照明であった。

技術の進歩ととあにエネルギ一資源は，化学製品の原 材料としてあ用いられるようになった。19世紀に始まっ た石炭の乾留に始まる石炭化学, 20世紀に発展した石油 の精留による石油化学の発展に引き続き, 現在は天然ガ スの主成分メタンを出発点としたいわゆる $C_{1}$ 化学が発 展している。

技術の進歩はまたエネルギー効率の最大限の発揮を目 指して進んできた。石炭を熱源とする蒸気機関に始まっ た効率追求は，ガソリンエンジン，ディーゼルエンジ ン, あるい恪種タービンの開発と改良を通じて現在む 行われている。最近のエネルギー効率向上のための研 究開発の対象は, 電気化学の原理に基づく燃料電池で ある。

個々の熱機関の効率向上と同時に，コンバインドサイ クル，コージェネレーションシステムなど，システムを 複合化することによって全体としての効率高度化を図る 努力む進めら机ている。その際，効率向上のための熱力 学的に重要なファクターは燃焼温度である。最初の機関 で仕事をした後す, 高温の排ガスは次のシステムです十 分な仕事をする能力を有し，順次その熱を使い切るまで 何段もの仕事をするいわゆる「熱のカスケード利用」を 可能とする。

(3) 輸送技術

产業, 経済が発達すると, 資源も重要な商品として翰 送されるようになった。固体の木材や石炭の場合には特 に大きな困難はなかったが，液体の石油となると特別の 容器が必要となり, 石油産業の初期には木製の標が用い られ，その名残がよく知られている石油の単位バーレル （bbl）である。その後，さらに大量の石油輸送のために 陸上ではパイプライン，海上ではタンカーによる輸送技 術が発展した。

これに対して，天然ガスは常温で気体でありエネルギ
一密度も低いことから，その輸送にはさらに技術的，経 済的困難が伴った。20世紀になって国内および近隣に大 規模ながス田が発見された欧米では，このガスを利用す るためのパイプラインの布設が進んだ。米国では第 2 次 大戦前に，欧州，ロシアでは1950年代以降にパイプライ ン網の整備が行われて, 天然ガス時代を迎えた。しかし パイプラインが布設できない場合は，天然ガスを有效に 活用する方法はなかった。極低温における天然ガスの液 化, 輸送, 䠉蔵による利用システム（LNGチェーン） は，低温熱力学の発展および優れた断熱材料の開発に基 づき，1960年代に実用化された。これによって天然ガス の遠距離海上輸送が可能となり，1970年代から島国であ る日本における天然ガスの大規模利用も始まった。

現在でも天然ガス利用上の最大の障害の 1 つは輸送で ある。そこで, 上り経済的な天然ガスの輸送および貯蔵 方法として，化学的に液化したり，水との包接物である メタンハイドレート化するシステムの研究開発が引き続 き行すれている。

(4) 貯蔵技術

燃料の需要には, 季節的, 時間的增減が大きい。固体 の木材や石炭の場合, 䝪蔵は最も容易であり, 液体の石 油の場合がこれに次ぐ。石油の貯蔵は通常タンクによっ て行われている。2 度の石油危機の後, 各工業国はいず れも消費数か月分の大量の備蓄を行うようになり，岩㙁 ドームや岩盤眝蔵などの地下眝蔵屯行われている。常温 で気体である天然ガスの眝蔵には, さらに技術的, 経済 的困難が伴う。欧米のガス利用国では, 需要における大 きな季節变動を吸収し，パイプラインに関する設備投資 を最小にするため，主として枯渴油がス田を利用した大 規模な地下貯蔵が行われている。その量は年間使用量の $20 \%$ から $40 \%$ にも上っている。一方，ガスの輸入を LNG で行っている日本においては, 貯蔵用 LNG タン クの建設にはばくだいな費用がかかるので，欧米のよう な大量の貯蔵施設は持たず，定期的な LNG 船の運航に 依存している。

\section{3. 人類はエネルギーに何を求めたか一人類の 発展にとってのエネルギー資源の役割}

\section{1 人類がエネルギーに求めたもの一高カロリー化}

エネルギー資源の価值は，何よりあまずどれだけ仕事 をする能力（ポテンシャルエネルギー）があるかで計ら れる。燃料資源の場合は燃㜔するときに発生する熱量が その尺度となる。

燃料資源の歴史的動きを発熱量によってたどってみる と，以下のとおりである。

$$
\text { 木 材 } 1,500-2,000 \mathrm{kcal} / \mathrm{kg}
$$




$$
\begin{array}{lc}
\text { 石炭 } & 5,000-8,000 \mathrm{kcal} / \mathrm{kg} \\
\text { 石 油 } & 9,000-11,000 \mathrm{kcal} / \mathrm{kg} \\
\text { 天然ガス } & 13,000 \mathrm{kcal} / \mathrm{kg}
\end{array}
$$

これを見ると，人類は燃料資源として単位当たりのよ り高い熱量, 高力ロり一化を追求してきたことが示され る。この中では, 特に木材から石炭への移行時の熱量 ギャップが極めて大きく，これが火の利用に勝るとも劣 らない産業革命と呼ばれる人類史の大変化をむらした 理由であることがわかる。

物質の発熱量はほぼ成分元素の燃焼熱の和に等しい。 主要成分の発熱量は，水素分子が約 $34,000 \mathrm{kcal} / \mathrm{kg}$, 炭素が 7,800 $\mathrm{kcal} / \mathrm{kg}$ となり, 水素含量の多い炭化水素 ほど発熱量が大きくなる。上記然料の元素組成を見る 上, 水素対炭素元素比は木材の $1 / 10$ 少 , 石炭 $1 / 1$, 石油 $2 / 1$ ，そして天然ガスの 4/1へと増加している。

このように燃料資源のたビってきた高エネルギー化へ の道は, 化学構造的に言うと高水素化への道であったこ とが示される。そしてメタン以上に水素比率の高い天然 資源がないとから，天然がスは究極の高エネルギー資 源であると言える。

\section{2 環境性一エネルギーに求められるもう 1 つの条 件}

\section{2 .1 人類をはぐくんだ地球の自然条件}

真空の宇宙に浮汃ぶ地球の表面温度は，太陽からの工 ネルギーの入射之地表からの放射という2 つの流れの平 衡によって決定される。これに加えて地球を取り巻く大 気圈中の炭酸がスや水蒸気などのガスによる蕰室効果が 存在し，大気成分による対流などのために温度勾配が生 じる。これらの結果として, 地表の平均温度は $15^{\circ} \mathrm{Cを}$ を保 っこととなり，地表の大部分では水は液体として，かつ 海として存在することとなった。地球が水の惑星と呼ば れるゆえんである。

多くの元素や単純な分子を溶かし込んだ原始の海中 は，宇宙加らの放射線や紫外線が適度に和らげられ，生 命の誕生と進化の舞台となったと考えられている。原始 の海で誕生した生物は, やがて大量の酸素を大気中へ排 出し，成層圈はオゾン層によって覆われることとなっ た。これにより，太陽からの紫外線の大部分がさえぎら れ，生物は陸上へあ進出することとなり，陸上と海上に 広がる地球生態系が成立した。その後も環境条件は幾度 屯変遷し，その中で適応した生物群が生き残って今日の 生態系を形作っているのである。約300万年前に現れた 人類もまた自然の一部であり，生態系の一部であった。

\section{2 .2 人類による地球環境の破壊}

（1）原始時代汃ら中世まで

約 200 万年以前から人類は道具などを用いることなど
により，生態学的な位置を超えて動物，植物を含めた自 然界の秩序を破壊し始めた。資源エネルギーの利用に上 る環境の㯖化は，古代においても存在した。エネルギー 資源として木材を主として使用していた時代，人口が集 中した古代都市においては，その使用量が木材の生成の 速さを上回り，周辺森林が消失したケースる見られる。 しかし，産業革命が始まるまでは，基本的にはエネル ギーの利用量は主要な資源である森林の再生速度と釣り 合っており，地球規模ではいわゆる持続可能なシステム であった。

\section{（2）産業革命以降の環境污染}

産業革命において主要エネルギー資源は，木材に比し て数倍のカロリーを持つ石炭に移行し，加利用量が急 速に增加した。このため，石炭の利用が集中する大都市 や工業都市では, 亜硫酸ガス, 油煙, 煤煙などの発生に よる大気污染が進行し，深刻な公害問題が発生した。急 速な人口堌加に伴う土地利用形態の变化は, 地球規模で 森林を始めとする生態系を破壊していった。大都市の公 害問題は，20世紀になって石油，天然ガスが新たなエネ ルギー源として登場し，また電化が進んで石炭の果たし ている役割に取って代わるまで，基本的には解決されな かった。石炭は20世紀の後半になって, 石油にエネル ギー資源の首位を奪われたが，それはエネルギー価格， 使い勝手，環境負荷などの総合的な経済的，技術的，社 会的評価によるものであり，資源の枯渴あるい供給力 の減少によるものではなかった。

石炭に取って代わった石油毛また，その然焼排気がス によって環境活染をむたらすこととなった。エネルギー 効率の高さ, 利便性などのため, 石油の使用量は加速度 的に上昇し，交通機関などを中心とした石油の使用によ る排気ガスは, $\mathrm{SO}_{\mathrm{x}}, \mathrm{NO}_{\mathrm{x}}$ の発生, 酸性雨の発生など, 大都市のみならず広域な，場合によっては国境を越えた 環境污染を引き起こし，深刻な社会問題をむたらした。 このため, 各国は公害対策に乗り出し，いくつかの工業 先進国では，ようやく環境污染の進行をくい止めつつあ るところである。

第 2 次大戦後の欧米にお括る天然がスの大規模利用 は，環境上加らも望ましいものであった。日本において 屯，1970年代加ら LNG の輸入による天然ガスの大規模 利用が開始されたが，こ机には大気污染公害への対策， 環境対策上の目的白含まれていた。天然ガスは主成分が メタンであり，1オウ分が含まれていないため，燃焼し て本 $\mathrm{SO}_{\mathrm{x}}$ を排出しない。また，当然のことながら重金 属や高分子の発ガン性の化合物む含んでいないので，そ れらを排出しない。 $\mathrm{NO}_{\mathrm{x}}$ の発生についてあ，すとすと 窒素原子を含んでいないので少ないうえ，燃烧条件を選 
ベばほとんどゼロにすることが可能である。

(3) 地球温暖化現象

産業革命以来の人類活動の影響は，生物界のみなら ず, 地球上の水質, 土壌，大気圈の下部加ら上部の成層 圈のガス組成に至るまで, 自然界のあらゆる面に広がっ てきている。現在に近づくほどその速度は増し，自然の 修復能力が追いつかない括それが出てきた。近年の資源 エネルギーのあまりにも急速な消費に対し，発生する炭 酸ガスの植物による固定なごが追いつかず，大気中の濃 度が増大している（図 1)。そのため大気温度が上昇し, 海水面の上昇や気候の变動を引き起こす抢それが指摘さ れている。

炭酸ガスの排出は，燃焼に際して組成中の炭素が酸素 と反応することによって生じる。したがって，炭素の比 率が少ないほど炭酸ガスの排出は少ない。水素に対する 炭素の比率をみると, 木材 $10 / 1$, 石炭 $1 / 1$, 石油 $1 / 2$ に 対し，天然ガスは極めて低く(1/4)，化学構造的には炭 素比率減少の方向であったということが示される。自然 界にはメタンより手水素に対する炭素の比率の低い炭化 水素は存在しないという意味で, 天然ガスは環境面から
あ究極のエネルギー資源であると言えよう。

\section{3 究極の資源エネルギー}

人類はエネルギーに対し，一方で高力ロリー，他方で 環境性を追求してきた。るれらは，化学的には一方は高 水素化，他方は低炭素化であるが，それらがたまたまメ タンという1つの分子によって㬰現されたことになる。 自然界に掞いてそれは天然ガスであり，その意味で天然 ガスは究極の資源エネルギーと言えよう。

歴史の各時点で, 人類は利用できる技術力に応じて資 源を選択し，その資源の持つ化学的，物理的なポテン シャルをできる限り利用しようと努力してきたとみるこ ともできる。しかしながら，その根本にあるのは，より 高い価值のあるエネルギーを求めるという人類の飽くな き欲求であり，技術力はそれに対する制約ではなく，そ れを実現するための手段であったと言えるのではなかる うか。

今後の人類の発展を展望するとき，人類が何を望むの か，何に洒徝を置くのか，よ゙のようなエネルギー，ある いはそれを利用する社会経斉体制を望むのかが最重要な ファクターであると考えられる。なぜなら，歴史が示す

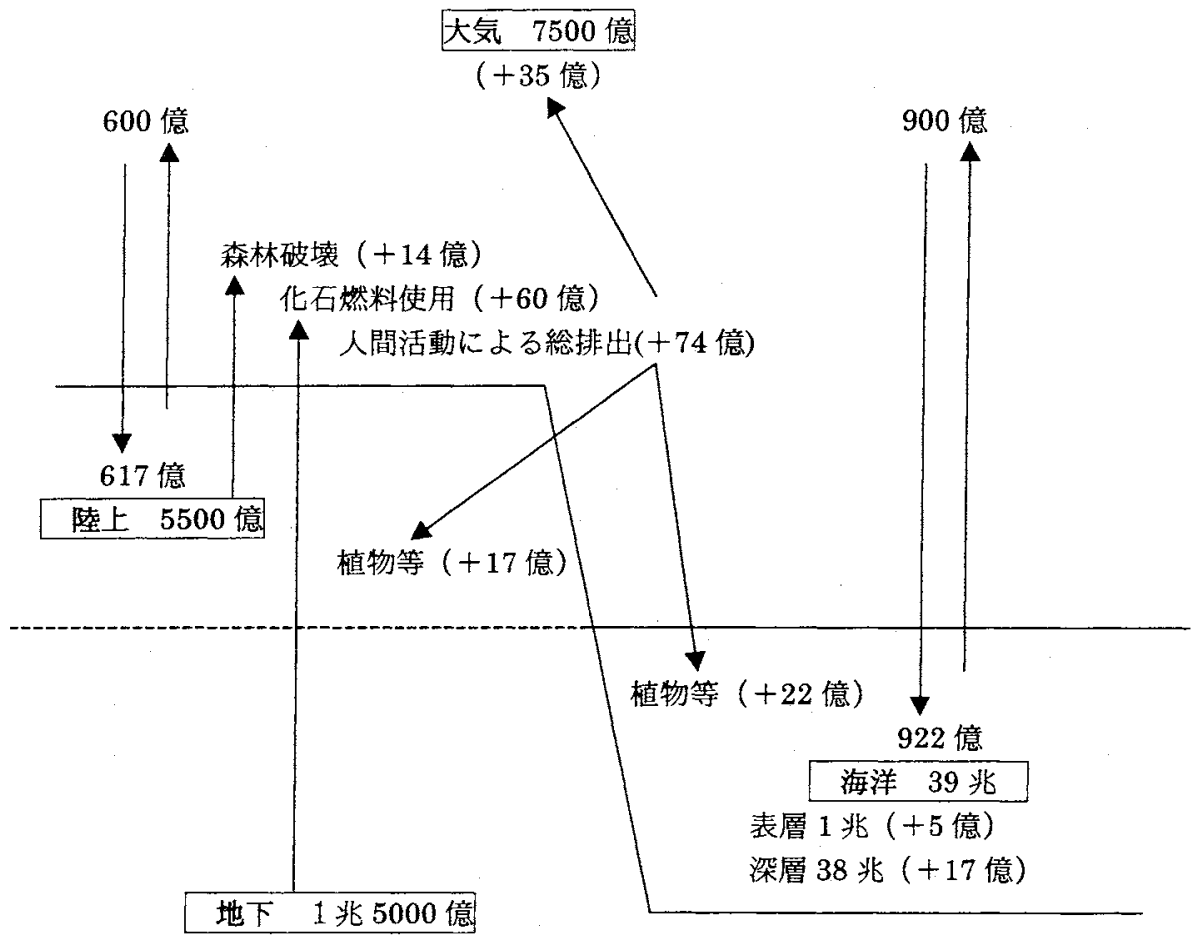

図 1 地球上の炭酸ガスの循環

1990年代前半の年平均値，単位炭素トン。毎年，人間活動（化石燃料の消費之森林 破壊など）による炭酸ガス排出量のうち，約半分の35億炭素トンが大気中に蓄積す る (U.S. Department of Energy, 1999k基づく)。 
ように，人類はどのような困難があろうとも，洒值のあ るものを獲得するためにはあらゆる努力を惜しまないで あろうし，その困難を解決する技術の開発を決してあき らめないであるうと考元られるからである。

\section{21世紀における天然ガスの役割}

本章では，21世紀に扔いて天然ガスが期待される役割 を果たすことができるかどうかについて，資源量，環境 性，エネルギー効率，供給体制の 4 万向加ら考察する。

\section{1 天然ガスの究極可採資源量の堌加は期待できる}

石油鉱業連盟のスタディ報告（1997）によると，天然 ガスの可採年数として, 残存確認可採埋蔵量を約 4,800 兆 $\mathrm{ft}^{3}$ として約 49 年分，未発見回收潜在量を約 4,600 兆 $\mathrm{ft}^{3}$ として約 46 年分，あわせて残存究極可採資源量を約 9,400 兆 $\mathrm{ft}^{3}$ として約95年分としている。原泊の場合は, 確認約 9,200億 bbl の約41年と, 未発見約 4,000 億 bbl の約18年，あわせて残存究極可採資源量約 1 兆 3,200 億 bbl の約59年になっており, 天然ガスの活うが35年以上 多い。熱量換算でむ天然ガスの残存可採究極資源量は原 油換算約 1 兆 5,700 億 $\mathrm{bbl}$ となり, 原油の場合上り約 2,500 億 $\mathrm{bbl}$ 多い。

天然ガスが石油の次のエネルギー資源の主役となるに は，今後ともさらに十分な資源量が発見される必要があ ると思われるが，その可能性については以下の点加らか なり高いと考える。

(1) 探鉱の成熟度

確認埋蔵量の数字については，従来の探鉱開発活動に 基づくもので不確定要素は少ない。問題は未発見資源量 中加ら将来発見され, 回収可能々期待される可採埋蔵量 であり，この見積すりの精度については，探鉱活動の成 熟度に反比例して不確定な要素が大きくなると考元ら れる。

天然ガスの未発見回収潜在量は究極資源量の約 $40 \%$ と され，原油の場合の約 $20 \%$ に比べれば，今後の操鋐に待 つ部分が多い。また，天然ガスの場合，既生産量す既発 見資源量の約 $31 \%$ ，究極資源量の約 $19 \%$ でしかなく，原 油の既生産量が既発見資源量の $45 \%$ ，究極資源量の $36 \%$ であるのに比べて少ない。このように，天然ガスの探鉱 生産活動は，まだ原油活ど成熟していないと言えよう。

原油の発見量のカーブは1920年代に立ち上がり，1960 年前後を頂点として1970年代まで続く幅広いピークを持 つが，1980年代からは次第に減少している。一方，天然 ガスの発見量注1940年代から急增し，1970年台に高い ピークをもち，その後滅少しているが80年代以降む一定 のレベルを維持している。このトレンドからす，天然が スの探鉱は原油ほど成熟していないと言えよう。
これら原油，天然ガスの発見量の推移を見ると，超巨 大フィールドの発見に依存していることがわかる。原油 の場合，地球上には可採埋蔵量50億 bbl 以上の超巨大 油田は47油田あるが，上位20位には60年代以降の発見が ない。さらに，70年代に21位，22位，39位，41位の 4 油 田が発見された後は，80年代，90年代とむ超巨大油田は 1 油田屯発見されていない。一方, 天然ガスの場合は, 埋蔵量 30 兆 $\mathrm{ft}^{3}$ 以上の超巨大ガス田は34フィールドであ るが，70年代にはこのうち 1 位を含む10フィールドあの 発見があった。その後の発見は，80年代には 1 ガス田， 90 年代には 2 ガス田と減少したが，それでも 90 年代の発 見がス田のうち 1 つは第 9 位である。このような結果か ら見て屯，天然ガスの探鉱は原油の場合ほど成熟してお らず，20年ほどの遅れがあると言えよう。

なお，未発見潜在回収量の不確実性を反映するため， Mastersたち（1994）はこれを単一の数字でなく確率分 布で報告している。この考えそのあのは合理的なむので あると思われるが，その分布曲線には問題があるのでは ないかと考える。それは天然ガス原油す，その分布曲 線で最頻度值（そード值）を100とすると，少ない回収 量の $5 \%$ 期待值を 62 , 多い場合の $5 \%$ 期待值を 123 とど ちらも同じとしていることである。これは，探鉱開発の 熟成度を無視した機械的な分布の与え方であり，原油よ り情報が少ない天然ガスのほうには, 当然, 不確定性を 考虑したより幅広い分布を与えるべきであるう。

(2) 石油システム

石油システムから天然ガスの追加発見が期待される理 由の 1 つは，天然ガス鉱床の深度である。鉱床形成上， 天然ガスの䟼存深度は原油より大きいとされ，例えば Hunt の教科書（1995）によれば, 地温公配 $3{ }^{\circ} \mathrm{C} / 100 \mathrm{~m}$ の地域に打いては, API 50 度以下の通常の原油の下限 深度は約 4,600 $\mathrm{m}$ であり，4,600 $\mathrm{m}$ から $5,800 \mathrm{~m}$ では軽 質油，コンデンセート，ウェットガスとなり， $5,800 \mathrm{~m}$ 以深ではドライガスが主となる。従来の探鉱深度では主 要なガス賦存層の多くは未探鉱であり，今後の探鉱活動 の深部化によって，ガス鉱床発見の可能性は増大すると 考えるのが妥当であろう。

次に述べるメタンハイドレートとの関連で注目される のは，その下部の遊離がスの集樍である。きわめて移動 しやすいガスを封じ込めるには，シール性能の上い帽岩 が必要である。その順位は，ガス八イドレート，蒸発 岩, 低浸透率加低孔隙率の頁岩となっている。世界の 超巨大ガス田の多くはロシアおよび中東に分布するが, ロシアの場合は八イドレートを伴う永久凍土が，中東の 場合は蒸発岩がそれぞれ帽岩となることが多いとされ る。今後の天然がスの探鉱対象として，極地あるいは深 
海のハイドレートを帽䇹とする鉱床がターゲットとして 考えられる。

(3) 非在来型天然ガス

種々の非在来型天然ガスの中には，存在が実証され， あるいはすでにある程度の生産実績があり，将来の技術 進歩, 経済社会条件などの変化によっては, 中長期的に 天然ガスのソースとして期待できるものが相当量存在し ている。

タイトサンドガス, コールベッドメタン, シェールガ スの3種類のガスは，すでに米国において生産実績を上 げており，1994年の年産量は合計3.6兆 $\mathrm{ft}^{3}$ となり，全 米生産量の $20 \%$ にっている。これら3 種類のガスの原 始鉱量は全世界で約 10,000 兆 $\mathrm{ft}^{3}$ を超えると推定され る。究極可採鎕量は，米国のタイトサンドの場合，原始 鉱量 1,200 兆 $\mathrm{ft}^{3}$ に対し 622 兆 $\mathrm{ft}^{3}$ し $50 \%$ 以上の回収が可 能との推定が行われている。仮に 3 種類のガスの回収率 がともに $50 \%$ とすると，究極可採鉱量は5,000兆 $\mathrm{ft}^{3}$ 以 上となる。

上記 3 種以外に，米国においては地圧水溶性ガスの存 在が報告され，原始鉱量として5,700兆 $\mathrm{ft}^{3}$ というばく だいな量が推定されているが，現在の技術と経凨条件で は商業化は困難として, 可採埋蔵量の算定は行われてい ない。また, 同ガスについては, ロシアから旧ソ連地域 の原始鉱量ししてさらにばくだいな86,000兆 $\mathrm{ft}^{3}$ という 値が報告されている。

一時話題となった地球深層ガスは存在が証明されてお らず，検討の対象から外すべきであろう。

現在最泉注月を集めているメタン八イドレートは, 存 在が証明されており, 原始鉱量として700,000兆 $\mathrm{ft}^{3}$ と のばくだいな推定值も報告されている。しかし，商業化 のための技術的，経済的検討は緒に就いたばかりであ り，可採鉱量について論じるのは時期尚早で, 今後の調 查に期待されるところである。

ここに述べた地球深層ガス以外の非在来型ガスは存在 が証明されているので，21世紀になって技術がさらに進 歩し, また経済社会条件の展開によっては, 在来ガスに 匹敵する程度の回収は期待できよう。

以上みてきたように，天然ガスの資源量については探 鉱の成熟度からも，石油システムからも，現時点の確認 埋蔵量に加えて, 未発見回収量からの相当量の埋蔵量の 追加が今後期待され，かつ非在来型天然ガスからの回取 量も期待されることから，たとえ相当量の需要増を見込 んだとしても，少なくとも今後 100 年間は量的制約の問 題は生じないと考える。

\section{2 環境性}

日本エネルギー学会の最近のデキスト（1999）によれ
ば，各種然料のライフサイクル分析の結果，温室効果ガ スの放出レベルは，石炭 100 , 石油 73, LPG 70 に対 L，LNGは60टいう低い值であることが示されている。 また，天然ガスコジェネレーションと従来システム（石 泊火力発電 $+\mathrm{A}$ 重油ボイラー）を比較すると，同じ電 力 $1 \mathrm{kWh}$ および熱 $1.7 \mathrm{Mcal}$ を得る場合に，炭素排出量 を従来の $346 \mathrm{~g}$ から $222 \mathrm{~g}$ に $35 \%$ も減少させることがで きる上算定される。

このように，天然ガスは他の資源に対して環境性が優 れているとはいえ，やはり炭酸ガスを排出することには 変わりはない。したがって，天然がスの採取から燃焼に 至る全サイクルにおける完全な排出ガス管理，および排 出された炭酸ガスの経済的隔離技術（捕集，転用，長期 保存）の開発に取り組む必要がある。

炭酸ガスの隔離の主要な方法は, 化学的処理, 物理的 処理, そして生物学的処理である。化学的処理として は，カルシウムとの炭酸塩などを作り建材などに利用す る方法, 物理的処理ししては膜などで濃縮した後, 地層 に圧入する方法，液体炭酸ガスやハイドレートにして深 海に沈める方法, 生物学的娌理ししては植物に光合成で 吸収させる方法などがある。どの方法が有効であるか は，炭酸ガスの発生する状況によるが，今後天然がスの 利用にあたっては，炭酸ガスの処理のしやすさにっいて の技術的，経济的検討を併せて行っていく必要がある。

炭酸ガスの隔離は，省エネルギー燃料転換とならん で，炭酸がス削減のための重要な手段となるう。

\section{3 エネルギー効率}

天然ガスの高いエネルギー効率は，水素組成が高く， 発熱量, 燃焼温度と屯に極めて高いので, いわゆるエネ ルギーのカスケード利用に最適であることから生じる。 これを活用するための種々の技術の現状之課題は以下の とおりである。ガス利用技術の開発は今後ますます活発 化すると考えられ，天然ガスの利用価值す一層增大する と期待される。

\section{(1) コンバインドサイクル発電}

まず天然ガスを燃焼させてガスタービンェンジンを回 し, 次にその高温排気ガスにより蒝気夕ービンを回し， 两者あわせて高い発電效率を得るシステムである。した がって，タービン燃焼温度が高いほど熱効率が向上す る。我が国では，LNG 発電によるコンバインドサイタ ル発電プラントは1980年代から各電力会社によって導入

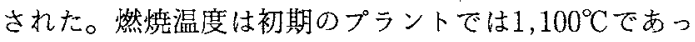
たが，その後 $1,300^{\circ} \mathrm{C}$ 引き上げられ，これに従い熱効 率も $43 \%$ 加ら $48 \%$ に上昇している。現在開発中のもの は，さらに燃烇温度 $1,500^{\circ} \mathrm{C}$, 熱効率 $53 \%$ を目指してい る。高い燃陞温度が得られる天然ガスの特性を生かした 
エネルギーのカスケード利用の代表的な例である。

(2) コジェネレーション

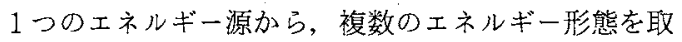
り出すことを言い，通常は熱と電気を取り出す。ガスエ ンジン，あるいはガスタービンで発電機を回して発電す るとともに, 排気ガスや冷却水の廃熱を温水または蒸気 として回収し，冷房，給湯，暖房に利用することによっ て，高い総合エネルギー効率を得るシステムよなる。我 が国では，一次エネルギーの有效利用度は平均約34\%に 過ぎないのに対し，ガスコジェネレーションでは70\%か ら80\%の高い総合効率が実現されている。ガスコジェネ レーションの普及は, 省エネルギーおよび環境対策上最 あ有力な方法の1つであると考えられている。

(3) ガス空調

ガス空調は, 今後の天然ガスの最終利用形態の中で最 も増加が多いと予想されている分野である。フロンを用 いない吸収式冷温水機ガス冷房は，オゾン磻保護ととも に地球温暖化の防止にも役立っている。排ガスからの熱 回収, 溶液熱交換器の効率向上など，高効率化に関する 技術開発省着実に進み，ガス冷温水機の省エネルギーは 1970年代加らの20年間に，大型機で32\%，中小型機で $53 \%$ 達成している。ガス冷房は冷熱量で我が国の全冷 房の10\%をまかなうようになったが，これは電力にして 400 万 $\mathrm{kWh}$ を超え，発電所 4 加所分に相当する。今後 ともがス冷房の堌加は，ガス需要の季節变動の平準化， 夏期の電力ピークの緩和，石油代替エネルギーの推進に あ大きな役割を果たすすのと期待される。

（4）末利用エネルギーの活用と他のエネルギーとの併 用

都市ゴミ焼却余熱，下水処理温排水，河川水，海水の 熱など，未利用のエネルギーは多い。例えば，東京首都 圏の年間末利用エネルギーは，790兆 kcal となり，原油 換算では 5 億 2,500 万 bbl/年，140万 bbl/日というばく だいな量となる。このエネルギーを都市ガス燃焼と效率 的に結び付ける地域給湯および冷暖房，スーパーゴミ発 電などのさまざまな展開が進んでいる。

天然ガスは単独で用いるだけでなく，石炭，石油，あ るいは太陽光熱などの自然エネルギーなどとの併用にお いて，その高い熱効率と環境性によってトータルの工ネ ルギー効率，利便性，環境性などを高めることができ る。今後, 天然ガスが21世紀のエネルギーの主役へと移 行していくうえで，この分野の利用法の重要性が増して いくと思われる。

(5) 天然ガス自動車

炭酸ガス排出量に占める自動車の比率は数十\%と高 く, 削減が求められている。天然ガス自動車は, $\mathrm{SO}_{\mathrm{x}} や$
ススなよ゙の粒状物質を排出せず，ガソリンやディーゼル 車に比べて， $\mathrm{NO}_{\mathrm{x}}$ や炭酸ガスの排出量が少ない。炭酸 ガスについては，ガソリン車に比べて 2,3 割低減する ことが可能とされる。他のクリーンエネルギー自動車, 低排出車と比べ，バス，トラックがら軽自動車に至るま であらゆる車種がそろっているのが特幑である。課題は 走行距離とガス供給体制である。現在，世界では約100 万台がすでに利用されている。普及が遅れていた我が国 に和いても，90年代になって急速に増加し，1998年度は 前年度の2,093台に対し，約1,600台増の3,640台となり， 引き続き大幅な堌加が予想されている。

\section{(6) 燃料電池}

通常の電池は内部に化学エネルギーを䠉蔵しており， それを消費して電気エネルギーとして放出してしまえば 寿命を終える。これに対して然料電池では内部に化学エ ネルギーを持たず，常に外部から燃料と酸化剂を供給す ることによって，原理的には永久に電気エネルギ一を発 生し続けることができる。

燃料電池は電気化学反応によって, 燃料の持つ化学ポ テンシャルを直接電気エネルギーに変換する発電装置で ある。このため，エネルギー変換に伴って発生する損失 が少なく，容量にかかわらず約40\%の高い発電効率が得 られる。この変換は燃陞を伴わず，また機械的運動を経 ないため，排がスがクリーンであり，騒音や振動もきわ めて小さい。コジェネレーションに利用すると高い総合 的土ネルギー効率が得られる。

燃料電池は使用される電解質の違いにより 4 種に分類 される。このうちリン酸型の開発が最む進んでおり，実 用化段階に入った。原然料は主として天然ガスであり， ローカル発電, 小型コジェネレーションに用いられてい る。現在世界で 200 台近く運転されているが, 半数以上 は日本国内にある。溶融炭酸塩型および固体酸化物型 (固体電解質型とも呼ばれる) は,りン酸型の発展型と して開発が進められ，さらに高温の燃料電池としてより 高い発電效率, 総合エネルギー効率を目指している。中 型加ら大型の火力代替発電用である。これに対し固体高 分子型は，高効率でかつ小型化が可能で作動温度が低 く, 家庭用, 自動車用として現在開発が進められてい る。最近ダイムラーベンツ社が，2003年に燃料電池を動 力とした乗用車を南場に出すと発表し, 競合他社も開発 計画を発表した。

(7) マイクロガスタービン

最近欧米の複数のメーカーが, 相次いで $10 \mathrm{~kW}$ から $100 \mathrm{~kW}$ 級の小規模ガスタービンを開発し販売すると発 表した。主要な用途は安価な電力の供給である。既存の 競合するガスエンジンと比較して李，サイズ，重量，導 
入価格，メンテナンスコスト，環境性において優位性が あり，発電効率においても同等あるいはそれ以上の性能 を有すると考えられる。がス業界, 電力業界とも, 分散 型電源として購入を検討していると報じられている。ま た，小規模抢よび家庭用のマイクロコジェネレーショ ンシステムの発電機としてあ, 市場性が高いと考えら れる。

また，我が国ではガスエンジン，ガスタービンの特に 高温燃䡒ガスに接する部分を, 高温に強いセラミックに する研究が進められている。これによって40\%から50\% の高発電効率, また高温の廃熱による高いコジェネレー ション効率が期待されている。

(8) 天然ガス化学

天然ガスを原料とする天然ガス化学す発展しつつあ る。現在のところ天然がスの全消費量のうち, 約 $10 \%$ が 化学用原料となっている。用途の主流はメタンを改質し た合成ガスを経由するアンモニアとメタノールの製造で あり, 現在世界のこれら化合物合成の70\%から80\%を占 める主要製法となっている。現在の主要な研究対象は, より炭素数の多いオレフィン化合物の合成である。

メタンはその構造上, 水素リッチでああることから水 素源としても有用であり, 燃料電池用水素の主要原料之 して有望視されている。

(9) 化学的液化

天然ガスを化学的に常温で液状の物資に变換して, 輸 送性, 眝蔵性を改善し, 未利用資源の利用を促進するた めの技術開発が進められてきた。化学的液化には次の 3 方法が研究されてきた。

第 1 は, 合成ガスを経る方法で, 最も上く研究され実 績も上げている。メタノール，エタノールなど各種アル コール, ジメチルエーテル, フィッシャートロプシュ法 による液状炭化水素, 各種オレフィンの製造が行われ， 商業化も一部で進めら机ている。

第 2 は合成ガスを経ないメタンの直接酸化法であり, これが実現すれば省資源，省エネルギー上きわめて大き な意義がある。天然ガスが石油化学工業原料として使え るかどうかは，メ夕ノール，オレフィン類がメタンから 安価に合成できるかにかかっている。種々の方法や触 媒が研究されて抢り, 今後の技術の発展が期待されて いる。

第 3 は熱あるいはその他のエネルギーを与えて,メ夕 ン分子の $\mathrm{C}-\mathrm{H}$ 結合を解離させ, 重合を開始させる方法 である。いくつかの有望な触媒あるいは燃料電池型反応 器を利用した試みが報告されている。

(10) LNG 冷熱利用

我が国は天然ガスの大部分をLNG で輸入している。
LNG は大気圧下では $1 \mathrm{~kg}$ あたり約 $840 \mathrm{~kJ} の$ 冷熱を有

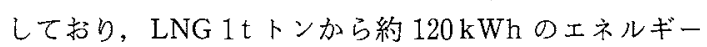
が利用可能とされている。LNG を気化させる場合, 熱 源を海水から得ている現状の冷熱の利用度は30\%以下で あり，ほかは未利用である。そこで海水に変わる冷媒を 用いることによって, 天然ガスのコンバインドサイクル 発電の廃熱を LNG 冷熱発電と複合させるシステムも提 案されている。この場合, LNG 気化 $1 \mathrm{t}$ あたり $60 \mathrm{kWh}$ と50\%以上の動力回収が可能と算定されている。今後さ らにLNG の冷熱利用を行ううえで制約となる，ガスの 需要変動パターンの影響を軽減するための蓄冷技術, 再 液化システムの開発が必要である。

\section{4 供給体制一ガスグリッド}

欧米の多くの工業国では，国境を越えた天然ガスの供 給体制の整備が進み，人々は電気や天然ガスを自由に選 択して利用することができるようになってきている。複 数のガス田加らの供給ラインと各消費地とのパイプライ ンネットワーク（グリッド）が形成されており，一部ガ ス田からの供給途絶の場合にあ柔軟な融通が可能であ りセキュリティは高い。我が国の場合はすでに人口の 50\%が天然ガス供給地域に居住しているとはいえ，それ は国土面積の約 $5 \%$ にしか過ざない。途上国の場合は一 部の産ガス国を除いて，供給体制の整備はほとんど進ん でいないのが現状である。これらの地域に住む人々や企 業が天然ガスのメリットを享受するためには，各国内の 主要地域を結ぶガスパイプラインのネットワーク，すな わちグリッドを作る必要がある。今後，特に分散型の発 電と熱供給に適したガスコジェネレーションシステム や, 環境負荷が少なく, 省エネルギーにも適した天然ガ 又自動車，燃料電池自動車の普及にとって，天然がス供 給地域の拡大は不可欠である。逆に，供給網の拡大に よって新しい形の天然がスの利用や需要が急速に増加す ると考えられる。

工篻先進国においては，エネルギー資源の主役は石崖 から，石油，そして天然がスへと移行してきた。現在， 発展途上国において大気污染などの環境問題の解決が大 きな課題となっている。今後, 環境問題の解決が国際的 に重要性を增してくると，途上国では先進国が石岑，石 油, 天然ガス上歩んだ順でなく，最初から天然ガスの利 用が図られる場合屯考えられる。

また，将来天然ガスに次いで水素ガスが主要なエネル ギー資源になるとしても，供給体制としてグリッドは必 要である。 


\section{5. 末来エネルギーへのかけ橋}

\section{1 理想のエネルギー一水素ガス}

第3章において考察したように，人類の求めてきたエ ネルギー資源の姿は高力ロリーと優れた環境性であり， これは化学的に言えば高水素化, 低炭索化の方向であっ た。その意味で，まさに天然ガスであるメタンが自然界 に扔ける究極の炭化水素資源であった。この方向ををさ らに推し進めていくと，それは水素ガス $\mathrm{H}_{2}$ に到達す る。

水素ガスを燃焼すると，高発熱量によって最高の工ネ ルギー効率が達成されるとともに，クリーンであり， ノ一カーボンであり，燃焼により発生するのは水のるで ある。今後の主流になると考えられる分散型のエネル ギー利用では，燃料電池が最も多く利用されると考えら れているが，水菜はその燃料として最適なものである。

将来の理想のエネルギーシステムとして考えられてい るのは，再生可能なエネルギーシステムであり，化石燃 料に依存しない水素の製造とその利用システムである。 その場合，水菜は太陽光などの自然エネルギーによる発 電，あるいは核融合発電による水の電気分解，およびバ イオマスから生産される。

\section{2 水素システム実現への課題}

水素システムの到来は，21世紀の後半から22世紀にか けてであろうと考えられている。

課題の 1 つは，水素の経済的な供給である。水の電気 分解用電力を再生可能エネルギーだけから経済的に取り 出すことが可能になるには，相当長い期間が必要である と考えられている。それまでの間，水素は LPG，ガソ シン，灯油などの石油製品，メ夕ノールなどの各種アル コール，バイオマスなどの化合物の改質，水の電気分解 などさまざまな手段によって製造されると考えられる。 その中でも最も有力な方法は，天然ガスであるメタンの 改質である。

あう 1 つの問題は水素ガスの輸送，脘蔵の困難性であ る。圧力容器, パイプラインによる方法については, 水 素脆性による材質破壊から水素ガスの漏洩が起こる危险 性があるが，安全で経済的な材翼が完成していない。水 素ガスを吸着させる特殊な金属の開発には，まだ時間が かかるようである。極低温により液体水素として輸送胕 蔵する万法は，見在のところきわめてコストがかかり， 実用的ではない。

\section{3 水素時代へのかけ橋ししての天然ガス}

天然ガスをエネルギー資源の主役とするシステムは， 21世紀だけではなく，その未来に到来すると予想される

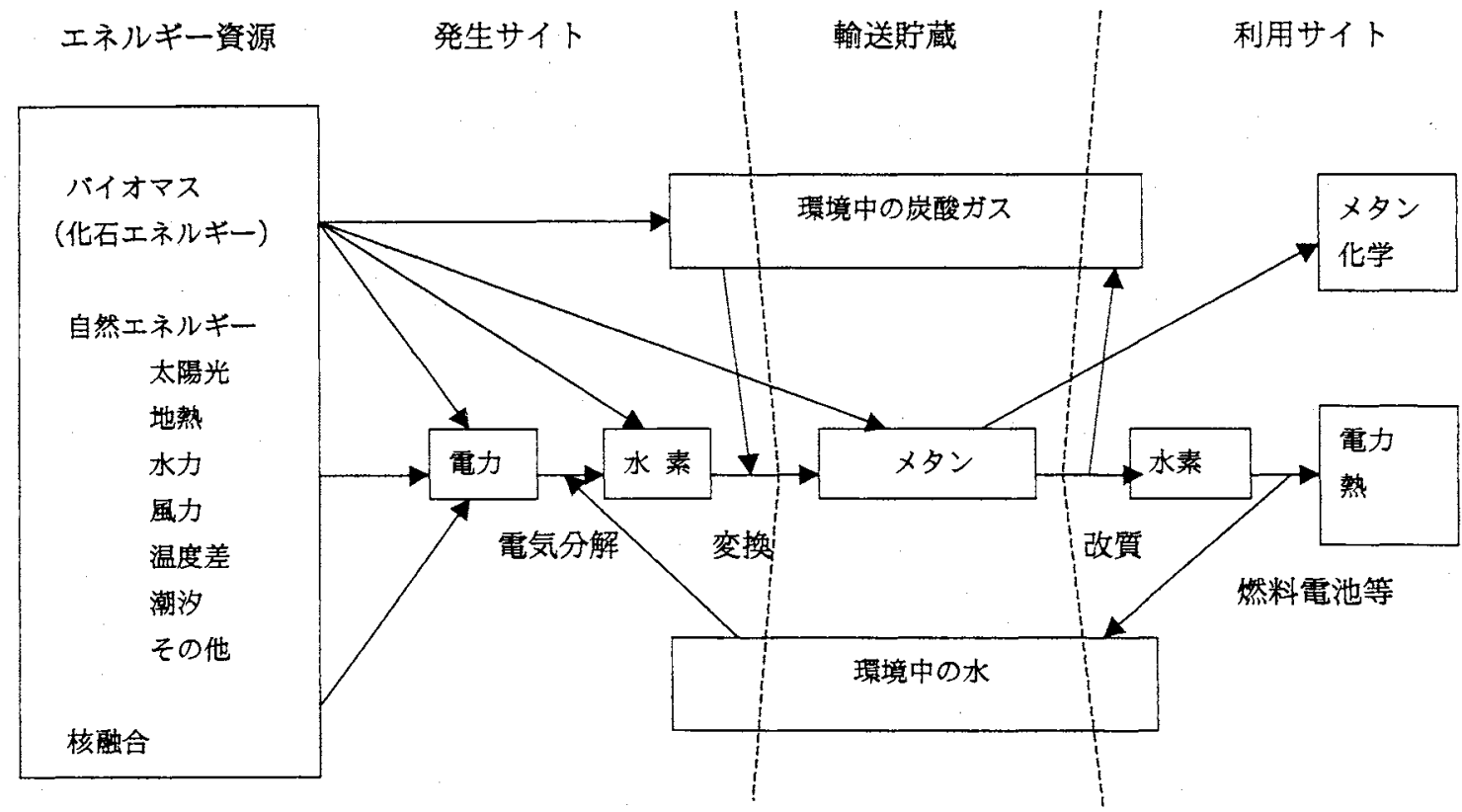

図 2 末来のエネルギーシステムへのかけ橋としてのメタン

再生可能なエネルギーから作られる水素を用いる未来エネルギーシステムに向け，メタ ンは水素の輸送眝蔵役として, 水素の原料として働く。バイオマス, 自然エネルギーな ビから製造される水素が増加するにつれ，化石エネルギーの役割は縮小する。 
水素時代へのかけ橋としてる，きわめて有効な役割を果 たすことができると考えられる。それは，再生可能な工 ネルギーシステムが確立するまで，そして水素の輸送眝 蔵に関する技術的問題が解決するまで，水素をメタンの 形で輸送，眝蔵し，利用するサイトにおいて改質して， 水素を取り出し利用するシステムである。すなおち，メ タンを水素の，言い換えればエネルギーのキャリアとし ても用いる方法である(図 2)。この方法の特徴は以下 のとおりである。

(1)メタンガスの輸送，貯蔵は確立された技術であ り，安全性が実証されている。

(2) 天然がスの各種インフラが活用できるので, 経斉 性, 利便性が高い。天然がスの輸送，貯蔵インフラ は，すでに世界の主要工業国で整備が進んでおり， 今後中国，インド，中南米，アフリカなど世界の他 の地域へのネットワーク拡大が予想されている。し たがって，21世紀の前半には世界中の大部分の国々 の人々が，必要に応じて天然がスを利用できる体制 (ガスグリッド) が整うと考えられる。

(3)メタンは水䒺に改質する際の炭酸ガスの発生量 が, 他のメタノールや LPG, ガソリンなどに比し て最も少ない。21世紀のエネルギー利用法として は，必要なときに必要な分だけ必要な場所で，燃料 電池などで効率よく分散利用する形態がますます增 加すると考えられる。炭酸ガスの処理に関しては， 大規模発電所などの大量発生に対しては，効率よく 回収することが可能であるが，小規模分散利用に よって発生する炭酸ガスを経済的に回収すること は，今後関連技術の開発努力が行われるとしても， 当分の間容易ではないと考えられる。燃料電池など へ水素を供給する場合，炭酸がスの発生の最す少な い天然ガスを改質することが，環境対策上最も優れ た方法であると考えられる。

(4) メタンは他のエネルギー資源加らの転換, 合成が 可能である。電力がさまざまなソースから発電され るように，他のエネルギー資源をメタンの形にして 輸送貯蔵することが可能である。将来, 水素がより 安価に製造できるようになると，炭酸ガスと反応さ せてメタン化する方法が炭酸ガスの隔離法としてす 考えられる。メタンが水素のキャりアとして，また 同時に炭酸ガスを吸収するシンクとして制くシステ
ムは，エネルギー効率からも環境上からあ優れたシ ステムになると考えられる。

(5) メタンは化学原料として炭素源が必要な場合にも 対応できる。

\section{6. 結語}

来るべき21世紀には，途上国を含めた世界の経済発展 と人々の生活向上のために，さらに多くのエネルギー資 源が必要となろう。一方, それに伴う地球環境の悪化を くい止める努力が今以上に必要となるう。天然がスは資 源量からむエネルギー効率からむ, そして環境負荷のい ずれの点からも, この矛盾する課題の解決のために中心 的な役割を果たすことができる。そして天然がスは単に それだけでなく，より理想に近ついた未来のエネルギー システム，すなわち化石燃料に依存しない水素の製造と その利用システムへの合理的なかけ橋となることができ るだろう。

\section{謝 辞}

発表の許可を頂いた(社)日本ガス協会および発表の機会 を与えていただいた石油技術協会に感謝いたします。ま た，種々ご教示いただいた日本ガス協会のかたがたに感 謝いたします。

\section{SI 単位換算係数}

$$
\begin{array}{rr}
\mathrm{bbl} \times 1.589874 & \mathrm{E}-01=\mathrm{m}^{3} \\
\mathrm{ft}^{3} \times 2.831685 & \mathrm{E}-02=\mathrm{m}^{3} \\
\mathrm{cal} \times 4.186=\mathrm{J} &
\end{array}
$$

\section{引用 文 献}

1) U.S. Department of Energy, 1999: Working paper for roadmapping future carbon sequestration R \& D. 1-5, U.S. Department of Energy.

2) Hunt, J. M., 1995 : Petroleum geochemistry and geology, second edition. 443-445, W. H. Freeman and Company.

3) Masters, C. D., Attanasi, E. D. and Root, D. H., 1994 : World petroleum assessment and analysis. Print of 14th World Petroleum Congress, 530-534.

4）日本エネルギー学会編, 1999：よくわかる天然ガス. 190-197, 日本エネルギー学会.

5）石油鉱業連盟編，1997：石油・天然ガス等の資源に 関するスタディ．45-132, 石油鉱業連盟. 